\title{
Timothy Verhoeven, Transatlantic Anti-Catholicism: France and the United States in the Nineteenth Century (New York: Palgrave Macmillan Press, 2010).
}

In tracing the growing international opposition to the social and political influence of the Catholic Church in the nineteenth century, Verhoeven charts the movement of ideas, books, and people back and forth across the Atlantic between France and the United States. Because the Catholic Church was an organization that notably transcended national boundaries in an age of nationalism, it makes a fine subject for transnational history. The height of anticlerical legislation in France is associated with the Third Republic, with its expulsion of the Jesuits in 1880 and separation of church and state in 1905. Yet the years 1840-1870, which coincided with the Second Empire and the activist papacy of Pius IX, deserve more study because they were pivotal to the evolution of liberal, republican thought. By shifting the focus to this earlier period and examining the cross-current of ideas of republicans in France and the United States, Verhoeven takes us into another realm, not that of laws or diplomacy that have traditionally been the domain of international history, but of stories, rumors, and causes célèbres that mobilized public opinion across continents.

Verhoeven begins with the story of the transatlantic stir that Father Hyacinthe, a French Carmelite monk, caused when he resigned from his order. His resignation letter appeared in Le Temps on 21 September 1869, was reprinted by newspapers throughout France the next day, and was front-page news in Chicago and Cleveland by October 5. The New York. Times reported that Hyacinthe was greeted by a crowd when he arrived in New York on October 16. He would later be visited by a bevy of intellectuals, including Harriet Beecher Stowe, Henry Ward Beecher, and Henry Wadsworth Longfellow. Interest in Hyacinthe was so great that publisher George Putnam rushed a translation of the Father's sermons and addresses into print. What caused all the excitement? Hyacinthe's letter decrying the Catholic Church's refusal to embrace political, intellectual, and social developments of the age, including secular humanism and the reconciliation of faith and science, struck a chord with those who admired the courage and independence of this dissenter. They also applauded his manliness in defying the papacy and criticizing clerical celibacy as unnatural.

After emphasizing that Hyacinthe's rebellion against the Vatican was understood in the United States in gendered terms, Verhoeven takes us back twenty years before Hyacinthe's arrival to examine the ideas of Michelet, Quinet, and Laboulaye at the prestigious College de France. The works of republican historian Jules Michelet were immediately snapped up by American publishers and translated into English titles, History of France (1845), Love (1859), and Woman (1860), because copyright protection did not apply to works written by foreign- 
ers. Lack of copyright protection facilitated the profusion of French works in the United States, and publishers of texts with provocative titles like Michelet's could sell twenty thousand copies in the first month. Michelet provoked both admiration and criticism when he advanced the idea that women were invalids physiologically, but exalted by their spiritual power. His Du prêtre, de la femme et de la famille, translated as Spiritual Direction and Auricular Confession in 1845, took on a decidedly anti-Catholic cast when it pitted the Catholic confessor as a rival for authority with the male head of the household. During dinner conversations, the priest's invisible, regressive presence was blamed for preventing wife and daughters from embracing the patriarch's progressive views.

Michelet's ideas contributed to a cult of domesticity that held that women's natural sentiments of love, sympathy, and compassion were best cultivated in the tranquility of the domestic sphere. The convent was imagined to be diametrically opposed to that sphere, and few incidents created a greater international outcry than that of Sister Barbara Ubryk, a nun held captive, naked, shivering, and covered with excrement in a convent in Cracow in 1869. Verhoeven brilliantly analyzes the parallels between the convent atrocity genre, so familiar in France, and the Indian captivity genre in the United States, and explains why both resonated so powerfully. He notes how Ubryk's story bolstered the cult of domesticity and the power of patriarchy by underscoring the humiliation and deprivation that women experienced in convents and the dangers that they faced in the outside world.

There are many dimensions to the transnational exchange of antiCatholic ideas, including the opportunities that people on both sides of the Atlantic took to reflect upon French or American exceptionalism. Verhoeven's genius is in revealing how anti-Catholic literature voiced fears both about encroachments on men's freedom in the political sphere and about encroachments on their privilege in the home. Within this book, with its straightforward title and modest format, lie treasures of insight and detail that exceed the scope of this short review.

Lindsay Wilson

Northern Arizona University

\section{Tiqqun. This is not a Program, trans. Joshua David Jordan (Cambridge: Semiotext, 2011).}

This is not a Program consists of two essays: "This is Not a Program" and "A Critical Metaphysics Could Emerge As a Science of Apparatuses." Although the two works address distinct issues, they both aim to draw conclusions from the failure of the revolutionary left. This Is Not a Program is not and does not claim 